\title{
Higher snowfall intensity is associated with reduced impacts of warming upon winter snow ablation
}

\author{
Adrienne M. Marshall ${ }^{1}$, Timothy E. Link ${ }^{1}$, Andrew P. Robinson ${ }^{2}$, John T. Abatzoglou ${ }^{3}$ \\ ${ }^{1}$ Department of Forest, Rangeland, and Fire Sciences, University of Idaho, Moscow ID 83844 \\ ${ }^{2}$ Centre of Excellence for Biosecurity Risk Analysis, School of BioSciences, University of \\ Melbourne, Melbourne, Australia \\ ${ }^{3}$ Department of Geography, University of Idaho, Moscow ID 83844 \\ Corresponding author: Adrienne Marshall (adriennemarshall@uidaho.edu)
}

\section{Key Points:}

- Winter snowfall intensity is associated with reduced accumulation season ablation, particularly at warmer winter temperatures.

- $\quad$ Projected changes in snowfall intensity may exacerbate ablation in maritime western U.S. mountains and buffer losses in interior ranges.

- As temperatures warm, a larger area will experience conditions in which snowpack ablation is sensitive to snowfall intensity.

This is the author manuscript accepted for publication and has undergone full peer review but has not been through the copyediting, typesetting, pagination and proofreading process, which may lead to differences between this version and the Version of Record. Please cite this article as doi: 10.1029/2019GL086409

This article is protected by copyright. All rights reserved. 


\begin{abstract}
Warming temperatures are altering winter snowpack accumulation and ablation. Physicallybased snowpack simulations have indicated that increasing precipitation intensity may buffer the impacts of warming on annual maximum snow water equivalents. Here, we assess this relationship using an observational dataset from the western U.S. and show that greater snowfall intensity is associated with reduced accumulation season ablation, particularly in warmer conditions. We also use outputs from a hydrological model to evaluate the effect of snowfall intensity on ablation in future climate scenarios. Snowfall intensity is projected to increase in the continental interior, which could reduce the average effects of warming on accumulation season ablation by as much as $6.3 \%$, and decrease in maritime climates, increasing the effects of warming on ablation by up to $6.0 \%$. These results indicate the importance of accurately modeling changing snowfall intensity and considering snowfall intensity in climate change impact assessments of snow-dependent ecosystems and water resources.
\end{abstract}

\title{
Plain Language Summary
}

The warming temperatures associated with climate change are impacting mountain snowpack, with major consequences for water resources. We assess the potential for snowfall intensity to mediate the effects of warming on mid-winter snowmelt, finding that higher snowfall intensity is associated with reduced melt during the snow accumulation season. Our findings suggest that in the western United States, increased snowfall intensity in the continental interior will likely reduce the effects of warming on winter snowmelt, while decreased snowfall intensity in maritime regions will increase the effects of warming on winter melt. These findings underscore the importance of accurately capturing changes in precipitation intensity in climate change projections.

\section{Introduction}

Two major features associated with anthropogenic climate change in the western United States (U.S.) are decreasing snowpack (Barnett et al., 2008) and increasing precipitation intensity (Giorgi et al., 2011; Min et al., 2011; Seneviratne et al., 2012). In the western U.S., warming temperatures have already resulted in large-scale declines in spring snowpack (Hamlet et al., 2005; Knowles et al., 2006; Mote et al., 2018; Pierce et al., 2008) due to both a transition from snow to rain (Klos et al., 2014) and increased ablation of winter snow. Decreases in spring snowpack are projected to continue into the $21^{\text {st }}$ century (Fyfe et al., 2017; Gergel et al., 2017; Marshall et al., 2019; Rhoades et al., 2018), and runoff timing in snowmelt-dominated watersheds will continue to advance (Stewart et al., 2004). The impacts of decreases in spring snowpack and advances in melt timing include reduced water supply and increased conflict between users (Berghuijs et al., 2014; Dettinger et al., 2015), and altered soil moisture (Harpold 
\& Molotch, 2015; Maurer \& Bowling, 2014), forest greenness (Trujillo et al., 2012), and carbon sequestration (Arnold et al., 2014) dynamics.

The increasing precipitation intensity associated with anthropogenic climate change is characterized by more frequent dry days (Polade et al., 2014), more precipitation occurring on wet days (Giorgi et al., 2011, 2014; Orlowsky \& Seneviratne, 2012), and increased relative contribution of atmospheric river events to annual precipitation in the maritime western U.S. (Gershunov et al., 2019). Both observations (Alexander et al., 2006; Frich et al., 2002; Karl \& Knight, 1998; Kiktev et al., 2003; Papalexiou \& Montanari, 2019) and projections (Meehl et al., 2005; Min et al., 2011; Tebaldi et al., 2006) indicate increases in precipitation intensity, including in the western U.S. (Kim, 2005; Ma et al., 2020). Although most research conducted on precipitation intensity has focused on rainfall, snowfall intensity will respond differently. Both theory and climate models suggest that the most extreme snowfall events will decrease much less than mean snowfall, and in some locations may even increase (Danco et al., 2016; Lute et al., 2015; O’Gorman, 2014, 2015).

Although changes in snow accumulation are predominantly caused by a warming-induced shift from snow to rain, changes in snowpack ablation are the result of changes in the snowpack energy balance and are subject to the alteration of processes that affect net radiation and turbulent fluxes, including snow albedo (Painter et al., 2017; Skiles et al., 2018), temperature, humidity (Harpold \& Brooks, 2018), and wind (Mott et al., 2018; Pohl et al., 2006). Changes in the simulated snowcover energy balance under more extreme precipitation regimes were found to reduce ablation during the snow accumulation season, thereby partially mitigating the effects of warming on annual maximum snow water equivalent (SWE) (Kumar et al., 2012). Three general reasons have previously been posited for this dynamic: first, deeper snowpacks require larger energy inputs to satisfy the cold content and initiate melt. Second, larger snowfall events contribute more negative advective energy to the snowpack than smaller events, increasing cold content. Third, in relatively intense, intermittent snowfall regimes, available energy is not optimally used for snowmelt due to the higher probability of complete melt-out early in the accumulation season. While the sensitivity of SWE ablation to snowfall intensity has been established in simulation experiments, it has not been tested with observational data, nor has the spatial distribution of these effects been assessed.

In this study, we test the empirical evidence for the effect of snowfall intensity on ablation during the snow accumulation season using observational data across the mountainous regions of the western U.S. In order to assess the importance of this effect in future climate conditions, we evaluate whether the effect is evident in spatially distributed snowpack simulations and quantify the impacts of projected changes in snowfall intensity on accumulation season ablation. 
Building on previous physically-based modeling simulations of snowfall intensity impacts (Kumar et al., 2012), we use evidence from both observed and simulated data to enhance scientific understanding and confidence in our findings.

\section{Methods}

\subsection{Historical data}

Daily SWE data were obtained from the National Resources and Conservation Service (NRCS) Snow Telemetry (SNOTEL) Network and the California Department of Water Resources (DWR) snow pillow network. Quality assurance and control is conducted by the NRCS; in addition, we removed water years in which more than $10 \%$ of the data were missing and conducted additional quality control on the California snow pillow data (Text S1). We also removed observations with less than seven days between first SWE and the date of peak SWE, or with less than $100 \mathrm{~mm}$ peak SWE. This resulted in the use of data from 818 stations and 20298 station-years of data, with an average of 25 years of data per station (Table S1). For each site and water year, data were extracted from the first date of snow accumulation until the date of peak SWE, and snowmelt and intensity metrics were calculated on this subset.

Previous work on precipitation intensity has identified many ways to represent both intensity and extremes (Alexander et al., 2006; Frich et al., 2002); we used the simple daily intensity index, in which total precipitation is divided by the number of days on which precipitation occurred. We applied the simple daily intensity index only to SWE accumulation, rather than total precipitation

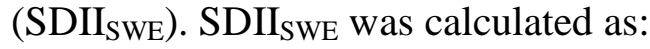

$$
S D I I_{S W E} i=\frac{\sum_{w=1}^{W} \text { snowfall }_{w i}}{W}
$$

where SDII $_{\text {SwE } \mathrm{i}}$ is the snowfall intensity for the $\mathrm{i}^{\text {th }}$ water year at a site, snowfall ${ }_{\mathrm{wi}}$ is the liquid snow water equivalent accumulation on days where accumulation is greater than $1 \mathrm{~mm}$, and $\mathrm{W}$ is the number of days on which snowfall occurs, from the first snowfall greater than $1 \mathrm{~mm}$ in a water year (1 Oct) until the date of peak SWE. Accumulation season ablation, the response variable, was calculated as peak SWE divided by the sum of snowfall liquid water equivalent that accumulated before the date of peak SWE.

SNOTEL temperature data were not used because of known inhomogeneities in the temperature record (Oyler, Dobrowski, et al., 2015). As an alternative, we used homogenized, infilled daily temperature data from TopoWx at SNOTEL stations (Oyler, Ballantyne, et al., 2015; Oyler et al., 
2016); these values are a precursor to the gridded TopoWx product. For California DWR snow pillows, we used the gridded TopoWx data from collocated grid cells. Daily $\mathrm{T}_{\min }$ and $\mathrm{T}_{\max }$ TopoWx values were obtained for each site over the period of record and averaged over November-March, hereafter referred to as "winter Tavg.” Temperatures averaged over a static calendar window may differ from temperatures during any given accumulation season, but serve as a stronger basis for site specific conditions during a given winter.

\subsection{Future scenarios data}

To determine the effects of snowfall intensity on accumulation season ablation under future climate scenarios, we used publicly available snowpack projections under future climate scenarios. Ten global climate models (GCMs) used in the CMIP5 (Taylor et al., 2011) were run for historical and representative concentration pathway (RCP) 8.5 conditions. These model outputs were statistically downscaled to $1 / 16^{\text {th }}$ degree grid cells (Abatzoglou \& Brown, 2012; Livneh et al., 2013); we obtained daily average temperature from these scenarios from 19512099. The Variable Infiltration Capacity (VIC) model was run with these downscaled results (Liang et al., 1994). These data contain several possible sources of uncertainty, including GCM variability, choice of downscaling method and reference dataset, lapse rates (Minder et al., 2010), and choice of hydrologic model, but represent historical snowpack variability well at SNOTEL sites (Gergel et al., 2017) and have been used extensively in hydrological research (e.g., Li et al., 2017; Marshall et al., 2019). Variability between GCMs is likely the largest source of uncertainty (Chegwidden et al., 2019).

We obtained daily SWE data for each grid cell containing a SNOTEL site from the VIC outputs. As with the SNOTEL data, $\mathrm{T}_{\text {avg }}$ was averaged over November-March, and SDII $\mathrm{SwE}_{\mathrm{S}}$ and accumulation season ablation were calculated for each water year. One important difference is

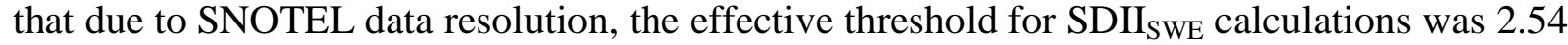

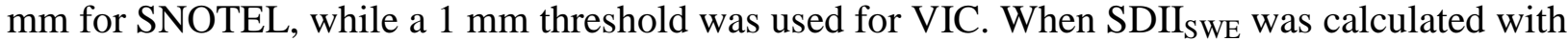
a $2.54 \mathrm{~mm}$ threshold with the VIC data, SDII swe values were highly correlated (correlation coefficient $=0.91$ ) with those calculated with the $1 \mathrm{~mm}$ threshold, suggesting that this decision had minimal impact on our results.

\subsection{Statistical models}

We used a generalized additive mixed modeling approach to test the relationship between SDII $I_{S W E}$ and winter season ablation, and its sensitivity to winter $\mathrm{T}_{\text {avg }}$ (Wood, 2017). This method was selected to account for spatial and temporal correlation structures within the data. The model for water year $j$ at station $i$ was constructed as: 


$$
\begin{gathered}
g\left(A_{i, j}\right)=\alpha+\beta_{j}+f_{1}\left(w y_{j}, N_{i}, E_{i}\right)+f_{2}\left(\text { elev }_{j}, \text { region }_{j}\right)+f_{3}\left(\text { SDII I }_{i, j}, T_{\text {avg } i, j}\right)+\varepsilon_{i, j} \\
\beta_{j} \sim N\left(0, \psi_{\theta}\right), \varepsilon \sim N\left(0, \Delta \sigma^{2}\right)
\end{gathered}
$$

where $g$ indicates a beta family of model with a logit link, A is accumulation season ablation, $\alpha$ is an intercept, $\beta_{\mathrm{j}}$ is a site-specific random effect, and $f_{1}, f_{2}$, and $f_{3}$ are tensor product smooths with cubic regression bases. In addition to winter $\mathrm{T}_{\text {avg }}$ and $\mathrm{SDII}$ SWE, the model includes northing $(\mathrm{N})$ and easting (E) using the Albers projection, elevation (elev), and snow region (as defined in Serreze, 1999). Each observation was weighted by annual maximum SWE in order to reduce the influence of very low snow years. A test of the model without the weights included suggested that weighting the model did not alter our overall conclusions. The model was developed iteratively to ensure that relevant model assumptions were met (Figures S1-S3). 
Tensor product smooths are a basis function appropriate for multivariate smooths with different units; similar approaches have been applied previously (Augustin et al., 2009, 2013; Montoya et al., 2014). The beta distribution is conceptually appropriate for this dataset but requires values to be inside the interval $(0,1)$. We reset zero values to be equal to half the smallest non-zero value; tests of this approach with zero values set to one-tenth the smallest non-zero value indicated that this threshold did not impact our conclusions. The site random effect was included to account for site-specific effects, such as topographic or vegetation effects, and $f_{1}$ and $f_{2}$ were included in order to account for spatiotemporally varying factors that were not otherwise included in the model, while $f_{3}$ tests the climatic variables of interest. The effect of SDII SWE $_{\text {on accumulation }}$ season ablation was determined via comparison of $\mathrm{R}^{2}$, Akaike's Information Criterion (AIC), and

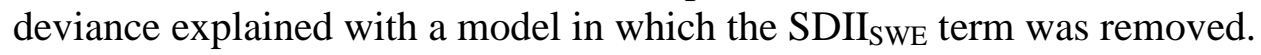

To test for possible confounding effects of omitted physically meaningful variables, we also tested models that included number of snowfall days, quantity of precipitation that fell in rainon-snow events, specific humidity from the date of first snowfall to peak SWE, and average downward shortwave radiation over the same period. Specific humidity $(q)$ and shortwave radiation were obtained from the gridMET dataset (Abatzoglou, 2013), using grid cells collocated with SNOTEL stations. These variables were added as independent cubic splines.

\subsection{Estimated effect size of changes in SDII $\mathrm{SWE}_{\mathrm{SW}}$}

To assess the impacts of snowfall intensity on accumulation season ablation under future climates, Equation 2 was fitted with the VIC data for each of the 10 GCMs, randomly sampling one in every four water years for computational efficiency. We also estimated the impact of projected trends in SDII $\mathrm{SWE}_{\mathrm{SE}}$ on changes in ablation. For each site and GCM, we calculated the 30-year average value of SDII ${ }_{\text {SwE }}$ in historical (1970-1999) and late-21 $1^{\text {st }}$ century (2070-2099) climates, and difference between these two climatologies. We subtracted this difference from the late $21^{\text {st }}$ century data in order to build a future time series with the difference in SDII $\mathrm{SWE}_{\mathrm{SE}}$ removed. Then, accumulation season ablation was modeled using the model fitted in Equation 2

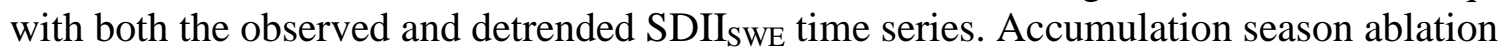
calculated with the detrended SDII SWE was subtracted from that calculated with SDII SWE from the original VIC time series for the years 2070-2099 in order to estimate the effects of projected changes in SDII $I_{S W E}$ on accumulation season ablation in the late $21^{\text {st }}$ century. These values were averaged over GCMs and water years. 


\section{Results}

3.1 Historical snowfall intensity impacts on accumulation season ablation

Figure 1 shows the spatial distribution of the snowpack variables used in our statistical model. Mean accumulation season ablation is generally lowest in the continental western U.S. and higher in the lower elevations of the Cascades as well as mountains of the southwest. SDII $\mathrm{SwE}_{\mathrm{SW}}$ is generally greater in maritime regions and lower in continental regions, likely due to the large contributions made by atmospheric rivers to overall winter snow accumulation in maritime regions (Lute \& Abatzoglou, 2014).

Results of statistical modeling with in situ data show that greater $\mathrm{SDII}_{\mathrm{SWE}}$ is associated with reduced accumulation season ablation, particularly in regions where winter $\mathrm{T}_{\text {avg }}$ exceeds $0{ }^{\circ} \mathrm{C}$ (Figure 2). For example, at the site with the median random effect for the average water year, when winter $\mathrm{T}_{\mathrm{avg}}$ is $3{ }^{\circ} \mathrm{C}$ and SDII $\mathrm{SwE}$ is $20 \mathrm{~mm} /$ day, the model predicts that $22.5 \%$ ( $\pm 2.3 \%$ s.e.) of accumulated SWE would ablate before the date of peak SWE. If SDII $\mathrm{SWE}_{\mathrm{S}}$ is reduced to 8 $\mathrm{mm} /$ day, the model estimates accumulation season ablation of $33.6 \%( \pm 3.0 \%)$; this suggests an average difference of $11.1 \%$. In contrast, when winter $\mathrm{T}_{\text {avg }}$ is $-3^{\circ} \mathrm{C}$, the same calculation suggests only a $3.4 \%$ difference in ablation. Comparisons with a null model support the hypothesis that

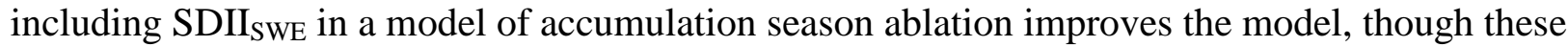
differences are relatively small (Table S2). The model indicates some non-monotonic effect of SDII $_{\text {SWE }}$ at high snowfall intensities and warm temperatures; however, in these cases, the date of peak SWE is relatively stochastic and dependent on individual storms, which yields highly variable values of accumulation season ablation.

Models including other potential important variables ( $q$, shortwave radiation, and number of snowfall days) indicated that inclusion of these variables slightly affected the quantitative

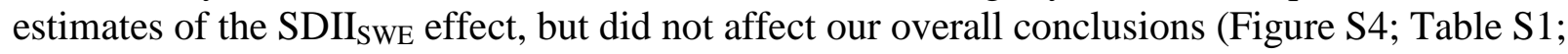
Text S3); therefore results are presented with these variables omitted. When $q$ was included, AIC was lower for the model excluding SDII ${ }_{\mathrm{SwE}}$, suggesting possible overfitting when SDII $\mathrm{SwE}_{\mathrm{S}}$ was included. However, $q$ and winter $\mathrm{T}_{\text {avg }}$ were very highly correlated (Pearson's $\mathrm{r}=0.75$ ), complicating the interpretation of results with both these terms included. These should be considered as a possible source of uncertainty when interpreting the effect size of our results.

The relatively small differences in fit statistics between the models including and excluding SDII $_{\text {SWE }}$ may be because snowfall intensity has the largest effects at temperature ranges that comprise a relatively small portion of the data. A model limited to observations for which winter 
$\mathrm{T}_{\text {avg }}$ was greater than $0{ }^{\circ} \mathrm{C}$ showed stronger evidence for the full model than the case with all observations included (Table S2; Figure S5). In contrast with model results from the full dataset,

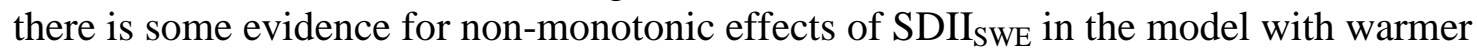
conditions, though these effects occurred only in regions with very warm winter temperatures,

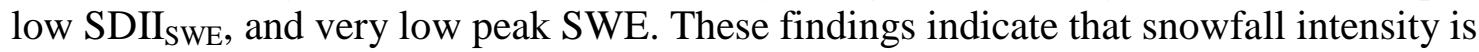
particularly important in warm conditions, between winter $\mathrm{T}_{\mathrm{avg}}$ values of $\sim 0$ to $+5{ }^{\circ} \mathrm{C}$. Of the area of the western U.S. where historical mean peak SWE was at least $100 \mathrm{~mm}, 11.3 \%$ on average was historically in this winter temperature range, but $44.3 \%$ is projected to fall in this winter temperature range in the RCP 8.5 scenario by 2070-99 (Figure S6).

\subsection{Snowfall intensity impacts based on simulated snowpacks}

When our statistical framework was applied to modeled VIC outputs, results indicate that SDII $_{S W E}$ is associated with reduced accumulation season ablation in all GCMs, primarily at warmer temperatures (Figure S8). Some GCM results have the same general shape as results based on measured in situ data; others suggest a non-monotonic effect of winter $\mathrm{T}_{\text {avg }}$ on accumulation season ablation at very warm winter $\mathrm{T}_{\text {avg. }}$. As with in situ data, the data in the regions contributing to non-monotonic tendencies have relatively warm winter $\mathrm{T}_{\text {avg }}(\sim 2$ to +5

${ }^{\circ} \mathrm{C}$ ); peak SWE at these locations is generally 4-9\% of the average peak SWE of the full dataset.

Comparisons with null models also support the hypothesis that SDII $\mathrm{SwE}_{\mathrm{S}}$ affects accumulation season ablation for all 10 GCMs (Table S2). The results suggest a larger difference between the full and null models than did the findings with in situ data. This may be due to the fact that the VIC data include more warm data points in future climates, conditions for which SDII $_{\mathrm{SWE}}$ is more likely to affect accumulation season ablation.

\subsection{Snowfall intensity importance in future climates}

Projected changes in $\mathrm{SDII}_{\mathrm{SWE}}$ exhibit distinct geographic patterns that are fairly consistent between GCMs (Figure 3; Figure S9). SDII ${ }_{\mathrm{SWE}}$ is generally projected to decrease in the maritime western and southwestern mountains, where it was historically largest, and increase in the cooler interior mountain west. An important exception is the higher elevation southern Sierra Nevada,

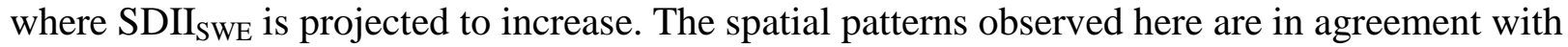
previous findings regarding the magnitude of extreme snowfall events (Lute et al., 2015; Serreze et al., 2001), and findings that individual snowfall events are particularly important in California (Lundquist et al., 2015). The projected decreases in SDII ${ }_{S w E}$ in maritime regions are likely due to warming temperatures and a transition from snow to rain; as large precipitation events increasingly occur as rain, rather than snow (Gonzales et al., 2019; Minder, 2010), SDII SwE $_{\text {S }}$ 
decreases. In contrast, at cooler continental sites and the highest elevation southern Sierra

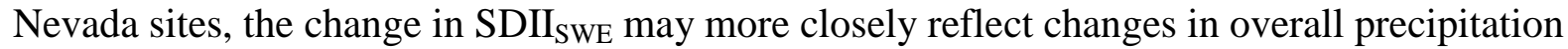
intensity, as the sites are colder and therefore less subject to transitions from snow to rain. Winter $\mathrm{T}_{\text {avg }}$ is projected to increase consistently, with the greatest increases in the continental interior (Figure S10). Accumulation season ablation is predominantly projected to increase, with a few sites showing decreases; these sites historically had relatively high ablation, so may have less potential for increases in ablation (Figure S11).

Figure 4 shows the average difference in estimated accumulation season ablation from 20702099 projected with our statistical model, using downscaled GCM outputs as compared to the same outputs with the trend in SDII $\mathrm{SWE}_{\mathrm{E}}$ removed. Average differences in ablation with and

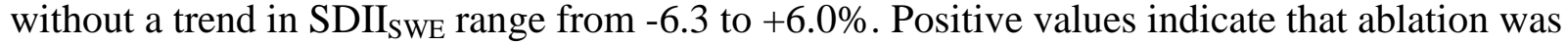
greater when the trend in SDII

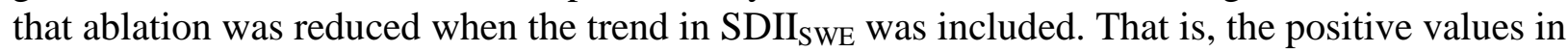
the lower elevation Sierra Nevada and Cascades indicate that projected increases in accumulation season ablation are likely to be exacerbated by the generally decreasing trends in SDII $_{\text {SwE, }}$ whereas the negative values in the Rocky Mountains and high elevation Sierra Nevada indicate that projected increases in ablation will likely be reduced by the generally increasing trends in SDII $_{\text {SWE. }}$

\section{Discussion and Conclusions}

Using both empirical and simulated snowpack data in historical and future climates, we found that greater average snowfall intensity is associated with reduced winter snow ablation at relatively warm winter temperatures. These effects were broadly similar between the empirical and modeled datasets, despite potential differences between the two, such as the spatial resolution of the model, lack of drifting snow, and incomplete physical representation of thermal gradients in the modeled snowpack, and potential errors in the estimated snow albedo in the modeled dataset (Essery et al., 2013).

Empirical studies based on observational data, such as this one, are subject to several limitations. Most importantly in this case, it is impossible to control for all potential omitted variables. While tests with shortwave radiation and number of snowfall days lend additional confidence to our

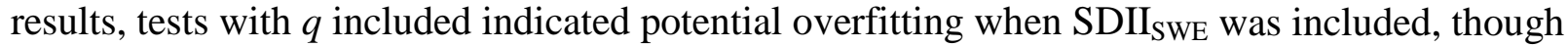
these results are difficult to interpret given the high correlation between $q$ and $\mathrm{T}_{\text {avg. Triangulated }}$ evidence between empirical and physically-based modeling approaches may reduce these limitations, as these two approaches have differing limitations. Indeed, this study tests empirical support for the conclusions of a physically-based modeling study (Kumar et al., 2012). Further 
mechanistic investigations using physically-based models could be used to further evaluate these findings by using spatially distributed approaches and testing for potential conflation with $q$ or other variables.

Kumar et al. (2012) suggested several mechanisms by which snowfall intensity may affect accumulation season ablation. We also propose two additional mechanisms. First, snowfall intensity may alter canopy interception. If snowfall occurs in relatively few, intense storms, then the forest canopy may more often reach its maximum snow interception capacity and unload more frequently. Higher snowfall intensity would therefore be associated with reduced interception losses. This effect should be present in the VIC model, which includes forest canopy interception, but to a much lesser degree in SNOTEL data because SNOTEL sites are usually located in small forest gaps. Second, snow albedo dynamics may change with altered snowfall intensity. On average, there should be longer intervals between storm events with higher snowfall intensity; this would be associated with greater albedo decay and thus greater potential for accumulation season ablation. This mechanism would act in the opposite direction of the effects observed in this study, and should be present in both the observed SNOTEL and simulated VIC model data (Andreadis et al., 2009). This effect may be complicated by the fact that small snowfall events may not completely mask the albedo of the underlying surface (Baker et al., 1991).

The increasing importance of snowfall intensity in warmer climates suggests a need for high confidence estimates of changes in snowfall intensity and represents one example of a mechanism that produces non-stationarity between seasonally averaged climatological variables and snowpack accumulation and subsequent runoff. Moreover, snow accumulation and melt models that account for the full snowcover energy balance should reflect the effects of snowfall intensity, while simpler temperature index models may not.

Given spatially varying projections of changes in snowfall intensity in the western U.S., altered snowfall intensity may reduce the effects of warming on winter snow ablation in the colder continental ranges by up to $6.3 \%$, and exacerbate the effect of warming in relatively warm maritime ranges by as much as $6.0 \%$. Particularly in regions where large sectors of the economy depend on a limited supply of water, and/or where aquatic species are on the margins of viability, these differences in accumulation season ablation may be critical. These findings demonstrate the power of integrating multiple lines of evidence to enhance confidence in scientific results in a sector with important implications for snow-dependent social and ecological systems. In conjunction with other climate-induced alterations to the snow energy balance, changing snowfall intensity is an important factor to consider in projections of climate-induced changes in snowpack and water resources, as well as associated adaptation planning. 


\section{Acknowledgements, Samples, and Data}

This work was supported by the National Science Foundation's IGERT Program (Award \#1249400). Suggestions from four anonymous reviewers and the editor considerably improved the manuscript. All data used in this study is publicly available through the Integrated Scenarios Project (https://climate.northwestknowledge.net/IntegratedScenarios/), TopoWx repository (http://www.scrimhub.org/resources/topowx/), the Natural Resources Conservation Service (https://www.wcc.nrcs.usda.gov/snow/), gridMET

(http://www.climatologylab.org/gridmet.html), and the California Department of Water Resources (http://cdec.water.ca.gov/dynamicapp/wsSensorData).

\section{References}

Abatzoglou, J. T. (2013). Development of gridded surface meteorological data for ecological applications and modelling. International Journal of Climatology, 33(1), 121-131. https://doi.org/10.1002/joc.3413

Abatzoglou, J. T., \& Brown, T. J. (2012). A comparison of statistical downscaling methods suited for wildfire applications. International Journal of Climatology, 32(5), 772-780. https://doi.org/10.1002/joc.2312

Alexander, L. V., Zhang, X., Peterson, T. C., Caesar, J., Gleason, B., Klein Tank, A. M. G., et al. (2006). Global observed changes in daily climate extremes of temperature and precipitation. Journal of Geophysical Research: Atmospheres, 111(D5), D05109. https://doi.org/10.1029/2005JD006290

Andreadis, K. M., Storck, P., \& Lettenmaier, D. P. (2009). Modeling snow accumulation and ablation processes in forested environments. Water Resources Research, 45(5), W05429. https://doi.org/10.1029/2008WR007042

Arnold, C., Ghezzehei, T. A., \& Berhe, A. A. (2014). Early Spring, Severe Frost Events, and Drought Induce Rapid Carbon Loss in High Elevation Meadows. PLOS ONE, 9(9), e106058. https://doi.org/10.1371/journal.pone.0106058

Augustin, N. H., Musio, M., Wilpert, K. von, Kublin, E., Wood, S. N., \& Schumacher, M. (2009). Modeling Spatiotemporal Forest Health Monitoring Data. Journal of the American Statistical Association, 104(487), 899-911. https://doi.org/10.1198/jasa.2009.ap07058 
Augustin, N. H., Trenkel, V. M., Wood, S. N., \& Lorance, P. (2013). Space-time modelling of blue ling for fisheries stock management. Environmetrics, 24(2), 109-119.

https://doi.org/10.1002/env.2196

Baker, D. G., Skaggs, R. H., \& Ruschy, D. L. (1991). Snow Depth Required to Mask the Underlying Surface. Journal of Applied Meteorology, 30(3), 387-392. https://doi.org/10.1175/1520-0450(1991)030<0387:SDRTMT>2.0.CO;2

Barnett, T. P., Pierce, D. W., Hidalgo, H. G., Bonfils, C., Santer, B. D., Das, T., et al. (2008). Human-Induced Changes in the Hydrology of the Western United States. Science, 319(5866), 1080-1083. https://doi.org/10.1126/science.1152538

Berghuijs, W. R., Woods, R. A., \& Hrachowitz, M. (2014). A precipitation shift from snow towards rain leads to a decrease in streamflow. Nature Climate Change, 4(7), 583-586. https://doi.org/10.1038/nclimate2246

Chegwidden, O. S., Nijssen, B., Rupp, D. E., Arnold, J. R., Clark, M. P., Hamman, J. J., et al. (2019). How Do Modeling Decisions Affect the Spread Among Hydrologic Climate Change Projections? Exploring a Large Ensemble of Simulations Across a Diversity of Hydroclimates. Earth's Future, 7(6), 623-637. https://doi.org/10.1029/2018EF001047

Danco, J. F., DeAngelis, A. M., Raney, B. K., \& Broccoli, A. J. (2016). Effects of a Warming Climate on Daily Snowfall Events in the Northern Hemisphere. Journal of Climate, 29(17), 6295-6318. https://doi.org/10.1175/JCLI-D-15-0687.1

Dettinger, M., Udall, B., \& Georgakakos, A. (2015). Western water and climate change. Ecological Applications, 25(8), 2069-2093. https://doi.org/10.1890/15-0938.1

Essery, R., Morin, S., Lejeune, Y., \& B Ménard, C. (2013). A comparison of 1701 snow models using observations from an alpine site. Advances in Water Resources, 55, 131-148. https://doi.org/10.1016/j.advwatres.2012.07.013

Frich, P., Alexander, L., Della-Marta, P., Gleason, B., Haylock, M., Klein Tank, A., \& Peterson, T. (2002). Observed coherent changes in climatic extremes during the second half of the twentieth century. Climate Research, 19, 193-212. https://doi.org/10.3354/cr019193

Fyfe, J. C., Derksen, C., Mudryk, L., Flato, G. M., Santer, B. D., Swart, N. C., et al. (2017). Large near-term projected snowpack loss over the western United States. Nature Communications, 8. https://doi.org/10.1038/ncomms14996

Gergel, D. R., Nijssen, B., Abatzoglou, J. T., Lettenmaier, D. P., \& Stumbaugh, M. R. (2017). Effects of climate change on snowpack and fire potential in the western USA. Climatic Change, 141(2), 287-299. https://doi.org/10.1007/s10584-017-1899-y

Gershunov, A., Shulgina, T., Clemesha, R. E. S., Guirguis, K., Pierce, D. W., Dettinger, M. D., et al. (2019). Precipitation regime change in Western North America: The role of 
Atmospheric Rivers. Scientific Reports, 9(1), 9944. https://doi.org/10.1038/s41598-01946169-w

Giorgi, F., Im, E.-S., Coppola, E., Diffenbaugh, N. S., Gao, X. J., Mariotti, L., \& Shi, Y. (2011). Higher Hydroclimatic Intensity with Global Warming. Journal of Climate, 24(20), 53095324. https://doi.org/10.1175/2011JCLI3979.1

Giorgi, F., Coppola, E., \& Raffaele, F. (2014). A consistent picture of the hydroclimatic response to global warming from multiple indices: Models and observations. Journal of Geophysical Research: Atmospheres, 119(20), 11,695-11,708. https://doi.org/10.1002/2014JD022238

Gonzales, K. R., Swain, D. L., Nardi, K. M., Barnes, E. A., \& Diffenbaugh, N. S. (2019). Recent warming of landfalling atmospheric rivers along the west coast of the United States. Journal of Geophysical Research: Atmospheres, 0(ja). https://doi.org/10.1029/2018JD029860

Hamlet, A. F., Mote, P. W., Clark, M. P., \& Lettenmaier, D. P. (2005). Effects of Temperature and Precipitation Variability on Snowpack Trends in the Western United States. Journal of Climate, 18(21), 4545-4561. https://doi.org/10.1175/JCLI3538.1

Harpold, A. A., \& Brooks, P. D. (2018). Humidity determines snowpack ablation under a warming climate. Proceedings of the National Academy of Sciences, 115(6), 1215-1220. https://doi.org/10.1073/pnas.1716789115

Harpold, A. A., \& Molotch, N. P. (2015). Sensitivity of soil water availability to changing snowmelt timing in the western U.S. Geophysical Research Letters, 42(19), 8011-8020. https://doi.org/10.1002/2015GL065855

Karl, T. R., \& Knight, R. W. (1998). Secular Trends of Precipitation Amount, Frequency, and Intensity in the United States. Bulletin of the American Meteorological Society, 79(2), 231-241. https://doi.org/10.1175/1520-0477(1998)079<0231:STOPAF>2.0.CO;2

Kiktev, D., Sexton, D. M. H., Alexander, L., \& Folland, C. K. (2003). Comparison of Modeled and Observed Trends in Indices of Daily Climate Extremes. Journal of Climate, 16(22), 3560-3571. https://doi.org/10.1175/1520-0442(2003)016<3560:COMAOT>2.0.CO;2

Kim, J. (2005). A Projection of the Effects of the Climate Change Induced by Increased CO2 on Extreme Hydrologic Events in the Western U.S. Climatic Change, 68(1-2), 153-168. https://doi.org/10.1007/s10584-005-4787-9

Klos, P. Z., Link, T. E., \& Abatzoglou, J. T. (2014). Extent of the rain-snow transition zone in the western U.S. under historic and projected climate. Geophysical Research Letters, 41(13), 2014GL060500. https://doi.org/10.1002/2014GL060500

This article is protected by copyright. All rights reserved. 
Knowles, N., Dettinger, M. D., \& Cayan, D. R. (2006). Trends in Snowfall versus Rainfall in the Western United States. Journal of Climate, 19(18), 4545-4559.

https://doi.org/10.1175/JCLI3850.1

Kumar, M., Wang, R., \& Link, T. E. (2012). Effects of more extreme precipitation regimes on maximum seasonal snow water equivalent: Extreme snowfall regime affects SWEmax. Geophysical Research Letters, 39(20). https://doi.org/10.1029/2012GL052972

Li, D., Wrzesien, M. L., Durand, M., Adam, J., \& Lettenmaier, D. P. (2017). How much runoff originates as snow in the western United States, and how will that change in the future? Geophysical Research Letters, 44(12), 2017GL073551. https://doi.org/10.1002/2017GL073551

Liang, X., Lettenmaier, D. P., Wood, E. F., \& Burges, S. J. (1994). A simple hydrologically based model of land surface water and energy fluxes for general circulation models. Journal of Geophysical Research, 99(D7), 14415-14428.

Livneh, B., Rosenberg, E. A., Lin, C., Nijssen, B., Mishra, V., Andreadis, K. M., et al. (2013). A Long-Term Hydrologically Based Dataset of Land Surface Fluxes and States for the Conterminous United States: Update and Extensions. Journal of Climate, 26(23), 93849392. https://doi.org/10.1175/JCLI-D-12-00508.1

Lundquist, J. D., Hughes, M., Henn, B., Gutmann, E. D., Livneh, B., Dozier, J., \& Neiman, P. (2015). High-Elevation Precipitation Patterns: Using Snow Measurements to Assess Daily Gridded Datasets across the Sierra Nevada, California. Journal of Hydrometeorology, 16(4), 1773-1792. https://doi.org/10.1175/JHM-D-15-0019.1

Lute, A. C., \& Abatzoglou, J. T. (2014). Role of extreme snowfall events in interannual variability of snowfall accumulation in the western United States. Water Resources Research, 50(4), 2874-2888. https://doi.org/10.1002/2013WR014465

Lute, A. C., Abatzoglou, J. T., \& Hegewisch, K. C. (2015). Projected changes in snowfall extremes and interannual variability of snowfall in the western United States. Water Resources Research, 51(2), 960-972. https://doi.org/10.1002/2014WR016267

Ma, W., Norris, J., \& Chen, G. (2020). Projected Changes to Extreme Precipitation Along North American West Coast From the CESM Large Ensemble. Geophysical Research Letters, 47(1). https://doi.org/10.1029/2019GL086038

Marshall, A. M., Abatzoglou, J. T., Link, T. E., \& Tennant, C. J. (2019). Projected Changes in Interannual Variability of Peak Snowpack Amount and Timing in the Western United States. Geophysical Research Letters, O(0). https://doi.org/10.1029/2019GL083770

Maurer, G. E., \& Bowling, D. R. (2014). Seasonal snowpack characteristics influence soil temperature and water content at multiple scales in interior western U.S. mountain 
ecosystems. Water Resources Research, 50(6), 5216-5234.

https://doi.org/10.1002/2013WR014452

Meehl, G. A., Arblaster, J. M., \& Tebaldi, C. (2005). Understanding future patterns of increased precipitation intensity in climate model simulations. Geophysical Research Letters, 32(18), L18719. https://doi.org/10.1029/2005GL023680

Min, S.-K., Zhang, X., Zwiers, F. W., \& Hegerl, G. C. (2011). Human contribution to moreintense precipitation extremes. Nature, 470(7334), 378-381. https://doi.org/10.1038/nature09763

Minder, J. R. (2010). The Sensitivity of Mountain Snowpack Accumulation to Climate Warming. Journal of Climate, 23(10), 2634-2650. https://doi.org/10.1175/2009JCLI3263.1

Minder, J. R., Mote, P. W., \& Lundquist, J. D. (2010). Surface temperature lapse rates over complex terrain: Lessons from the Cascade Mountains. Journal of Geophysical Research, 115(D14). https://doi.org/10.1029/2009JD013493

Montoya, E. L., Dozier, J., \& Meiring, W. (2014). Biases of April 1 snow water equivalent records in the Sierra Nevada and their associations with large-scale climate indices. Geophysical Research Letters, 41(16), 5912-5918. https://doi.org/10.1002/2014GL060588

Mote, P. W., Li, S., Lettenmaier, D. P., Xiao, M., \& Engel, R. (2018). Dramatic declines in snowpack in the western US. Npj Climate and Atmospheric Science, 1(1), 2. https://doi.org/10.1038/s41612-018-0012-1

Mott, R., Vionnet, V., \& Grünewald, T. (2018). The Seasonal Snow Cover Dynamics: Review on Wind-Driven Coupling Processes. Frontiers in Earth Science, 6. https://doi.org/10.3389/feart.2018.00197

O’Gorman, P. A. (2014). Contrasting responses of mean and extreme snowfall to climate change. Nature, 512(7515), 416-418. https://doi.org/10.1038/nature13625

O’Gorman, P. A. (2015). Precipitation Extremes Under Climate Change. Current Climate Change Reports, 1(2), 49-59. https://doi.org/10.1007/s40641-015-0009-3

Orlowsky, B., \& Seneviratne, S. I. (2012). Global changes in extreme events: regional and seasonal dimension. Climatic Change, 110(3), 669-696. https://doi.org/10.1007/s10584011-0122-9

Oyler, J. W., Dobrowski, S. Z., Ballantyne, A. P., Klene, A. E., \& Running, S. W. (2015). Artificial amplification of warming trends across the mountains of the western United States. Geophysical Research Letters, 42(1), 2014 GL062803. https://doi.org/10.1002/2014GL062803 
Oyler, J. W., Ballantyne, A., Jencso, K., Sweet, M., \& Running, S. W. (2015). Creating a topoclimatic daily air temperature dataset for the conterminous United States using homogenized station data and remotely sensed land skin temperature. International Journal of Climatology, 35(9), 2258-2279. https://doi.org/10.1002/joc.4127

Oyler, J. W., Dobrowski, S. Z., Holden, Z. A., \& Running, S. W. (2016). Remotely Sensed Land Skin Temperature as a Spatial Predictor of Air Temperature across the Conterminous United States. Journal of Applied Meteorology and Climatology, 55(7), 1441-1457. https://doi.org/10.1175/JAMC-D-15-0276.1

Painter, T. H., Skiles, S. M., Deems, J. S., Brandt, W. T., \& Dozier, J. (2017). Variation in Rising Limb of Colorado River Snowmelt Runoff Hydrograph Controlled by Dust Radiative Forcing in Snow. Geophysical Research Letters, 45(2), 797-808. https://doi.org/10.1002/2017GL075826

Papalexiou, S. M., \& Montanari, A. (2019). Global and Regional Increase of Precipitation Extremes under Global Warming. Water Resources Research, 2018 WR024067. https://doi.org/10.1029/2018WR024067

Pierce, D. W., Barnett, T. P., Hidalgo, H. G., Das, T., Bonfils, C., Santer, B. D., et al. (2008). Attribution of Declining Western U.S. Snowpack to Human Effects. Journal of Climate, 21(23), 6425-6444. https://doi.org/10.1175/2008JCLI2405.1

Pohl, S., Marsh, P., \& Liston, G. E. (2006). Spatial-Temporal Variability in Turbulent Fluxes during Spring Snowmelt. Arctic, Antarctic, and Alpine Research, 38(1), 136-146. https://doi.org/10.1657/1523-0430(2006)038[0136:SVITFD]2.0.CO;2

Polade, S. D., Pierce, D. W., Cayan, D. R., Gershunov, A., \& Dettinger, M. D. (2014). The key role of dry days in changing regional climate and precipitation regimes. Scientific Reports, 4, 4364. https://doi.org/10.1038/srep04364

R Core Team. (2018). R: A language and environment for statistical computing. Vienna, Austria: R Foundation for Statistical Computing. Retrieved from https://www.R-project.org/

Rhoades, A. M., Ullrich, P. A., \& Zarzycki, C. M. (2018). Projecting 21st century snowpack trends in western USA mountains using variable-resolution CESM. Climate Dynamics, 50(1-2), 261-288. https://doi.org/10.1007/s00382-017-3606-0

Seneviratne, S. I., Nicholls, N., Easterling, D., Goodess, C. M., Kanae, S., Kossin, J., et al. (2012). Changes in Climate Extremes and their Impacts on the Natural Physical Environment. In C. B. Field, V. Barros, T. F. Stocker, \& Q. Dahe (Eds.), Managing the Risks of Extreme Events and Disasters to Advance Climate Change Adaptation (pp. 109230). Cambridge: Cambridge University Press. https://doi.org/10.1017/CBO9781139177245.006 
Serreze, M. C., Clark, M. P., \& Frei, A. (2001). Characteristics of large snowfall events in the montane western United States as examined using snowpack telemetry (SNOTEL) data. Water Resources Research, 37(3), 675-688. https://doi.org/10.1029/2000WR900307

Skiles, S. M., Flanner, M., Cook, J. M., Dumont, M., \& Painter, T. H. (2018). Radiative forcing by light-absorbing particles in snow. Nature Climate Change, 1. https://doi.org/10.1038/s41558-018-0296-5

Stewart, I. T., Cayan, D. R., \& Dettinger, M. D. (2004). Changes in Snowmelt Runoff Timing in Western North America under a `Business as Usual’ Climate Change Scenario. Climatic Change, 62(1-3), 217-232. https://doi.org/10.1023/B:CLIM.0000013702.22656.e8

Taylor, K. E., Stouffer, R. J., \& Meehl, G. A. (2011). An Overview of CMIP5 and the Experiment Design. Bulletin of the American Meteorological Society, 93(4), 485-498. https://doi.org/10.1175/BAMS-D-11-00094.1

Tebaldi, C., Hayhoe, K., Arblaster, J. M., \& Meehl, G. A. (2006). Going to the Extremes. Climatic Change, 79(3-4), 185-211. https://doi.org/10.1007/s10584-006-9051-4

Trujillo, E., Molotch, N. P., Goulden, M. L., Kelly, A. E., \& Bales, R. C. (2012). Elevationdependent influence of snow accumulation on forest greening. Nature Geoscience, 5(10), 705-709. https://doi.org/10.1038/ngeo1571

Wood, S. N. (2017). Generalized Additive Models: An Introduction with R, Second Edition (2 edition). Boca Raton: Chapman and Hall/CRC.

\section{Figure captions}

Figure 1. Distribution of (a) accumulation season ablation as a percent of total SWE accumulation between the first date of snowfall and date of peak SWE and (b) snowfall accumulation intensity over the historical period from 1996-2015 shown for both in situ and VIC data. Only snow pillow sites with 20 years of data over the 1996-2015 period are included in the figure.

Figure 2. The fraction of total snowfall that ablates before the date of peak SWE modeled as a function of mean November-March temperature $\left(\mathrm{T}_{\text {avg }}\right)$ and snowfall intensity $\left(\mathrm{SDII}_{\mathrm{SWE}}\right)$ using in situ observations. For variables not plotted, fitted values are estimated at the median values, and the site with the median random effect was used. Changing the factor variables alters absolute values but does not change the contour shapes (Figure S7).

Figure 3. Change in average (a) accumulation season ablation, (b) winter $\mathrm{T}_{\text {avg, }}$, and (c) SDII $\mathrm{SwE}$ from 1970-1999 to 2070-2099, averaged across GCMs (individual GCMs for each variable in Figures S8-10). Only sites for which at least 3 GCMs had at least 10 out of 30 water years with 
greater than $100 \mathrm{~mm}$ peak SWE in the late $21^{\text {st }}$ century scenario are mapped to avoid sites with very few water years in the future scenario. Points are filled if at least $50 \%$ of GCMs agreed on a statistically significant change (two-sided t-test $\mathrm{p}<0.05$ ).

Figure 4. Effect of changes in SDII $I_{\text {SWE }}$ on future ablation rates, calculated as difference in accumulation season ablation predicted with GCM-projected SDII SWE $_{\text {versus difference-adjusted }}$ SDII $_{\text {SWE. }}$ Results are averaged over 10 GCMs and water years 2070-2099 (results for individual GCMs are in Figure S12). Histogram shows the distribution of mapped values. 

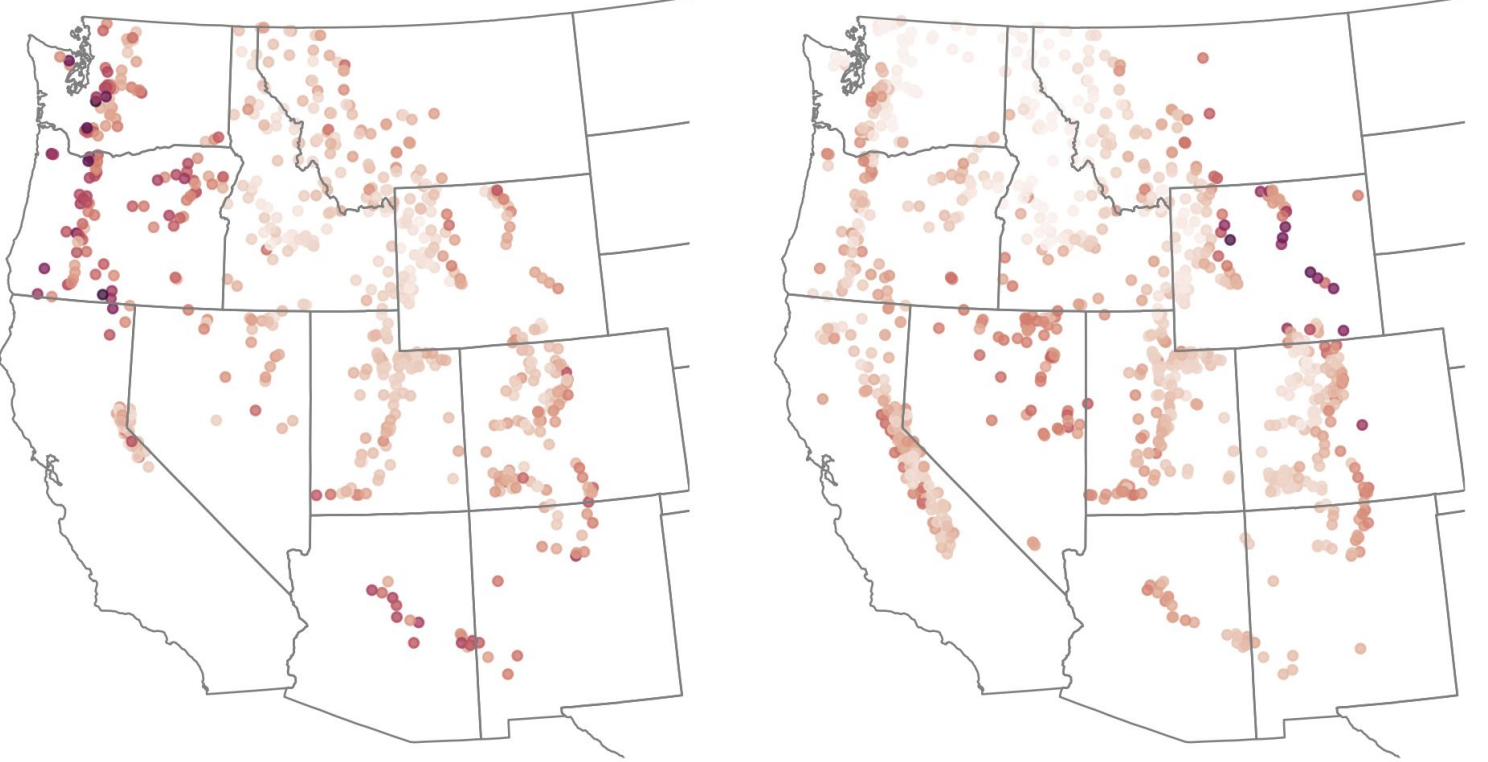

Accumulation

season

ablation

$(\%)$

$-50$

40

30

20

10
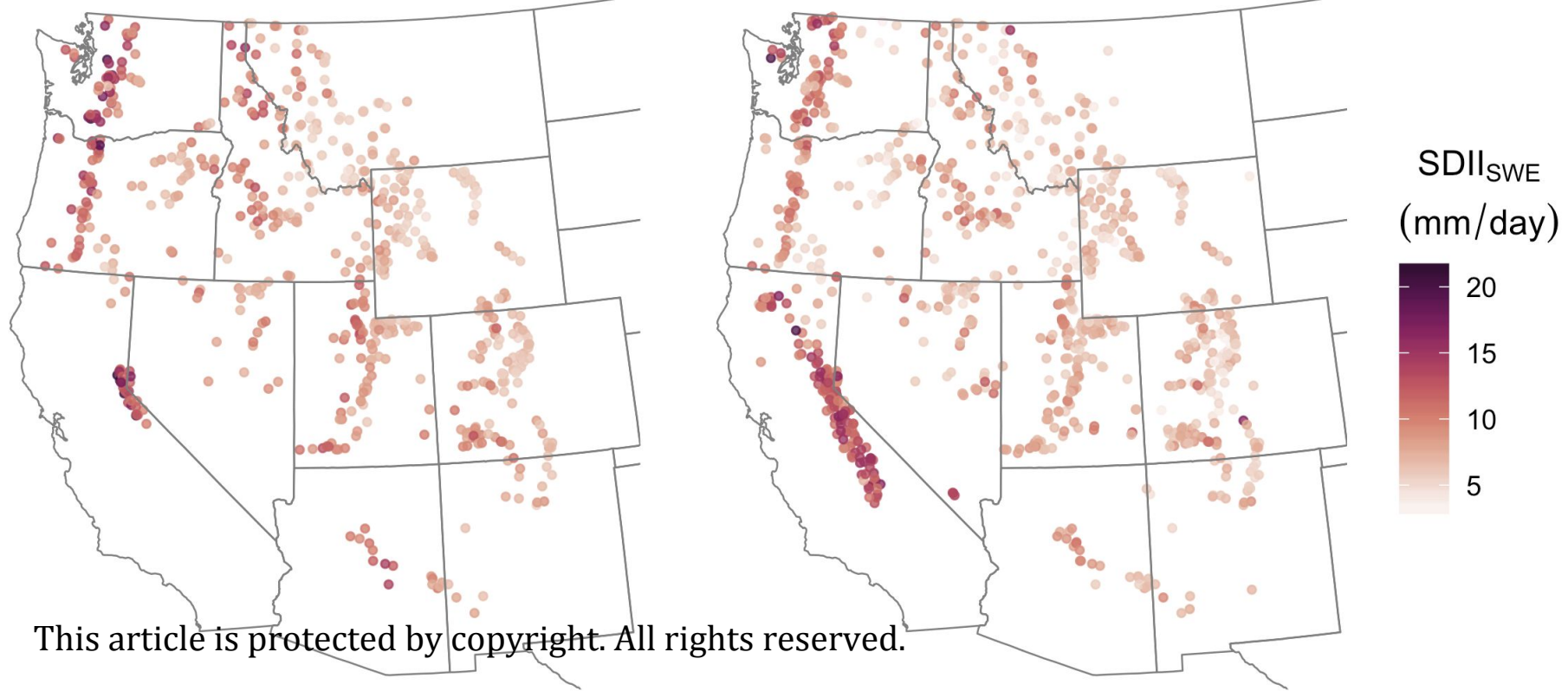

This article is protected by copyright. All rights reserved. 



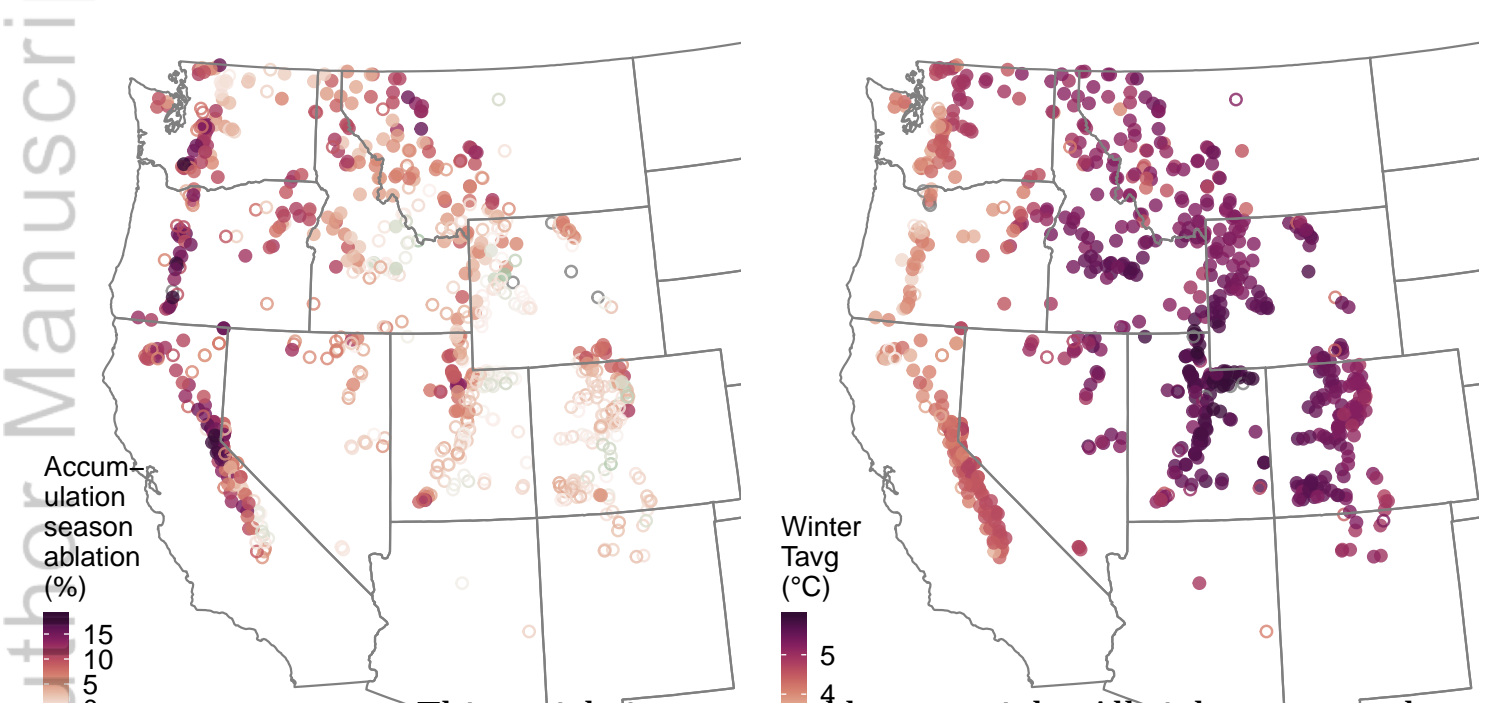

This article is protectedु by copyright. All rights reserved.

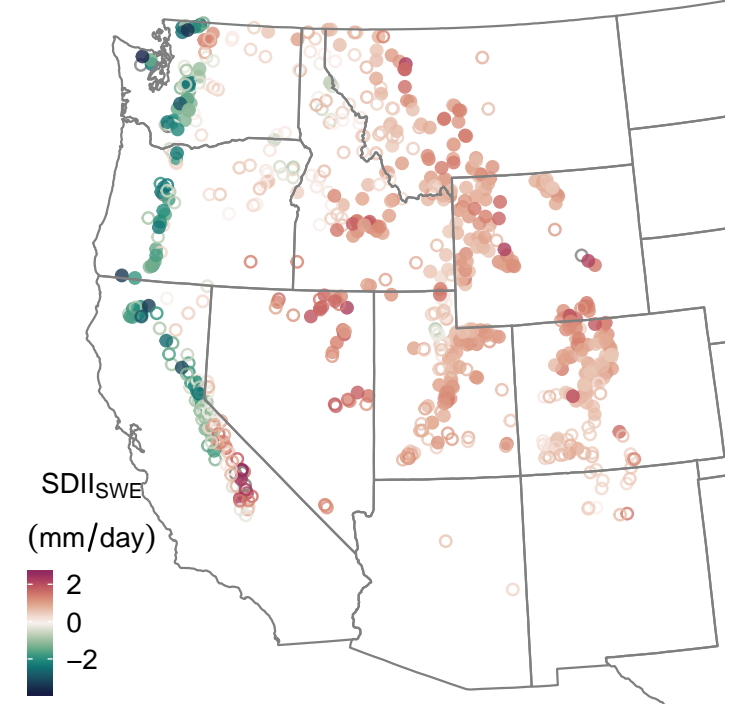




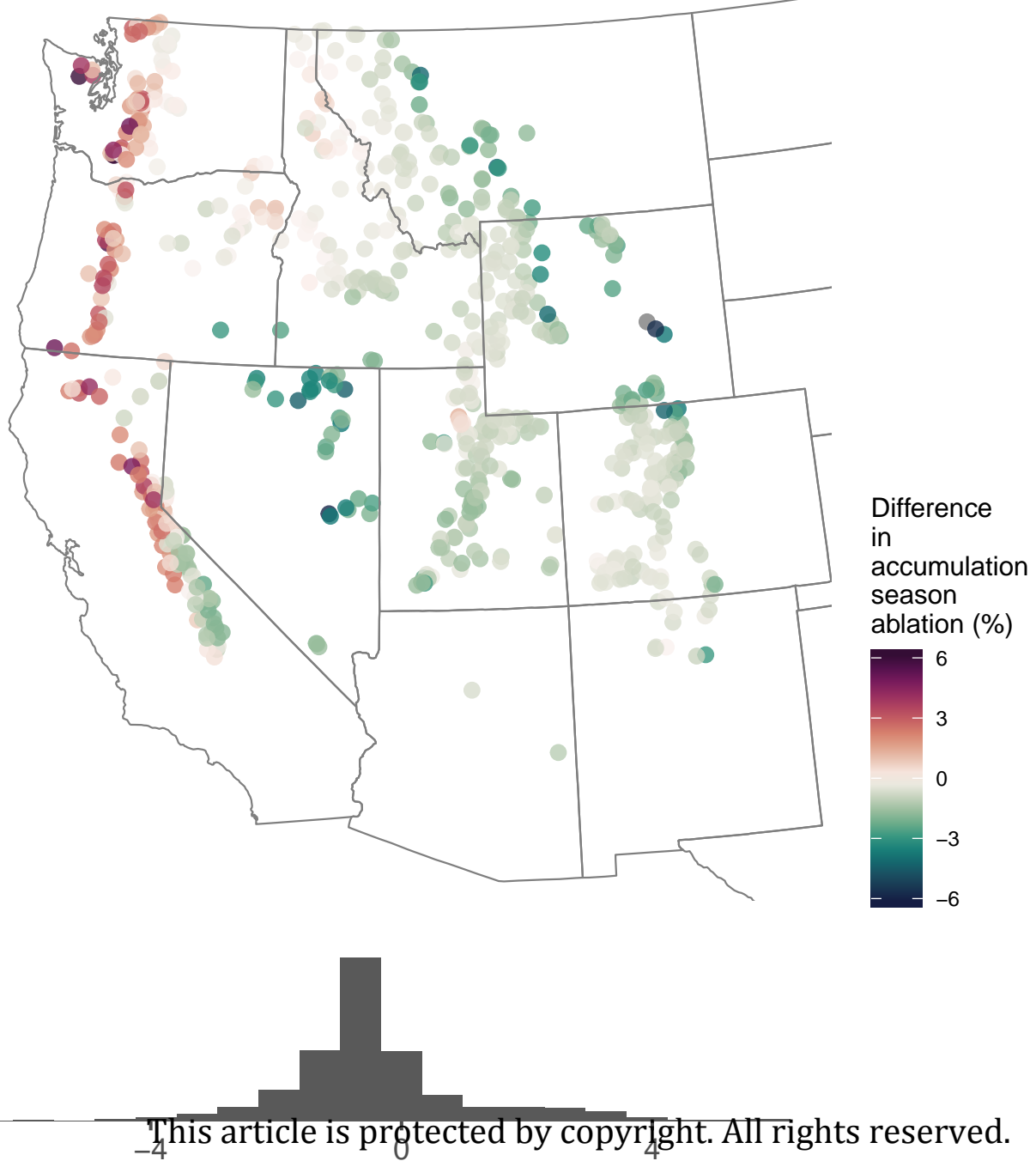




\section{University Library}

\section{- M M I E R R V A gateway to Melbourne's research publications}

Minerva Access is the Institutional Repository of The University of Melbourne

Author/s:

Marshall, AM;Link, TE;Robinson, AP;Abatzoglou, JT

Title:

Higher Snowfall Intensity is Associated with Reduced Impacts of Warming Upon Winter Snow Ablation

Date:

2020-02-28

Citation:

Marshall, A. M., Link, T. E., Robinson, A. P. \& Abatzoglou, J. T. (2020). Higher Snowfall Intensity is Associated with Reduced Impacts of Warming Upon Winter Snow Ablation. GEOPHYSICAL RESEARCH LETTERS, 47 (4), https://doi.org/10.1029/2019GL086409.

Persistent Link:

http://hdl.handle.net/11343/275407 